\title{
Non-regulated emissions and particle number emissions of two passenger cars with diesel-butanol blends
}

Biofuels represent one of the alternatives to obtain the $\mathrm{CO}_{2}$-neutral propulsion of IC-engines. Butanol, which can be produced from biomass, is considered and was investigated in the last years due to the very advantageous characteristics of this alternative fuel. Butanol can be easily and irreversibly blended both with light (gasoline) and heavier (diesel) fuels. Comparing with ethanol it has the advantages of: higher calorific value, lower hygroscopicity and lower corrosivity. It can replace the aviation fuels.

This paper presents the emission results obtained on two diesel passenger cars with different technology (Euro 2 and Euro 6c) and with addition of butanol to diesel fuel, as a part of the research project DiBut (diesel and butanol). Interesting results are given about some non-legislated (non-regulated) components, acetaldehyde (MeCHO) and formaldehyde (HCHO) and about the PN-emissions with/without DPF.

Key words: alternative fuels, non-legislated emissions, ultrafine particles, diesel particle filter, cold start emissions

\section{Introduction}

Butanol with chemical formula $\left(\mathrm{CH}_{3}\left(\mathrm{CH}_{2}\right)_{3} \mathrm{OH}\right)$ is a higher-chain alcohol, comparing to methanol or ethanol. There are different isomers of butanol, which have various positions of the hydroxyl group $(-\mathrm{OH})$ in the molecule.

The most common and important is n-butanol with a straight-chain structure and with the $\mathrm{OH}$-group at the terminal carbon $[1,2]$. The known research in diesel application, and also in the present project, was performed with n-butanol.

Some data of diesel-butanol blend fuels, according to [3, 4], are given in the following Table 1.

Table 1. Data of diesel fuel, n-butanol and their blends

\begin{tabular}{|l|c|c|c|c|c|c|}
\hline & $\begin{array}{c}\text { Ref. } \\
\text { Diesel }\end{array}$ & Bu05 & Bu15 & Bu30 & Bu50 & n-Bu \\
\hline $\begin{array}{l}\text { Density at } \\
15^{\circ} \mathrm{C} \text { in } \\
\mathrm{kg} / \mathrm{m}^{3}\end{array}$ & $\begin{array}{c}833- \\
837\end{array}$ & 833 & 832 & 828 & 822 & 806 \\
\hline $\begin{array}{l}\text { Net } \\
\text { calorific } \\
\text { value in } \\
\text { MJ/dm }\end{array}$ & 35.3 & 34.9 & 34.0 & 32.8 & 31.4 & 26.7 \\
\hline $\begin{array}{l}\text { Stoichio- } \\
\text { metric } \\
\text { air/fuel } \\
\text { ratio }\end{array}$ & 14.6 & 14.4 & 14.0 & 13.5 & 12.9 & 11.2 \\
\hline $\begin{array}{l}\text { Oxygen } \\
\text { content in } \\
\text { wt.- } \%\end{array}$ & $<0.03$ & 1.1 & 3.1 & 6.4 & 10.7 & 21.6 \\
\hline $\begin{array}{l}\text { H:C ratio } \\
\text { (molar) }\end{array}$ & 0.157 & 0.160 & 0.165 & 0.170 & 0.179 & 0.208 \\
\hline $\begin{array}{l}\text { Cetane } \\
\text { number }\end{array}$ & $52-54$ & $\approx 51$ & $\approx 48$ & $\approx 43$ & $\approx 35$ & $\approx 19$ \\
\hline
\end{tabular}

The higher oxygen content of butanol and butanol blend fuels $(\mathrm{BuXX})$ has similar advantages for engine-out (EO) emissions, like other alcohols or oxygenated fuels. The general tendency is lowering of $\mathrm{CO}$ and $\mathrm{HC}$ (especially for
SI-engines, EO) and lowering of PM (for diesel engines, EO) [5-17].

The importance of alternative, sustainable, $\mathrm{CO}_{2}$-neutral fuels for IC-engines cannot be too strongly emphasized. There is a lot of world-wide research on many variants of potentials fuels, substitutes or derivatives both: for SI- and CI-applications. Examples of interesting variety of research topics can be found in the CO-OPTIMA Publications Library of the US Department of Energy [18].

With the present research activities, the authors tried to complete the knowledge concerning nanoaerosol particle number (PN) and non-legislated gaseous emission components with the butanol blend fuels in diesel application. The project "Diesel-Butanol" (DiBut) consisted of two parts, which were performed on engine dynamometers and on passenger cars.

The first part of the results on engine dynamometers was presented in [19] and it confirmed the lowering of PN engine-out emissions with butanol blends $(\mathrm{BuXX})$. For the combustion it results that, with rising butanol shares of fuel blends, their characteristics are changing, causing aptitudes of quicker evaporation and of slower self-ignition. The last one is due to the significantly lower cetane number of butanol. The operating limit blend ratio concerning cold start, warm-up and low load operation is at approximately Bu30.

The modern exhaust aftertreatment of a Euro 6 engine consisting of DOC/DPF/SCR contributes to the elimination of $\mathrm{PN}$ and shows excellent deNO $\mathrm{N}_{\mathrm{x}}$-performances with butanol blends.

In the second part of DiBut-project butanol mixed fuels were applied on two diesel passenger cars with different engine technologies. These results of testing cars on chassis dynamometer, included cold starts and non-legislated gaseous emissions and they are subject of the present paper.

An important problem by application of alternative, and biogene fuels in diesel engines, is the lubricity (concerning the injection system) and the long-term impact on lube oil [20-23]. For butanol special lubricating additives can be 
applied. Nevertheless, this problem was not investigated in the present project.

\section{Test vehicles, fuels and lubricants}

Two vehicles were used for the present tests. An older car (Euro 2), with traditional concept of injection (distributor pump) and exhaust after-treatment (DOC) and a newer one (Euro 6c), with common rail injection and exhaust aftertreatment $\left(\mathrm{DPF}+\mathrm{deNO}_{\mathrm{x}}\right)$.

The most important data of the test vehicles are given in the Table 2.

Table 2. Data of test vehicles

\begin{tabular}{|c|c|c|}
\hline Vehicle & $\begin{array}{c}\text { Opel Astra } \\
\text { DI16V } \\
\text { V1 }\end{array}$ & $\begin{array}{c}\text { VW Passat Variant V } \\
\text { 2.0TDI } \\
\text { V2 }\end{array}$ \\
\hline Cylinder & 4 & 4 \\
\hline Overall displacement $\left[\mathrm{cm}^{3}\right]$ & 1994 & 1968 \\
\hline Power $[\mathrm{kW}]$ & 60 & 110 \\
\hline Injection type & $\begin{array}{c}\text { DI } \\
\text { distr. pump }\end{array}$ & $\mathrm{DI} / \mathrm{CR}$ \\
\hline Fuel & diesel & diesel \\
\hline Weight empty [kg] & 1390 & 1621 \\
\hline Transmission & M5/Front & M7/Front \\
\hline Matriculation & 20.01 .1998 & 09.02 .18 \\
\hline Turbocharging & yes & yes \\
\hline Exhaust aftertreatment & DOC & DOC, DPF, SCR \\
\hline Emission level & Euro 2 & Euro $6 \mathrm{c}$ \\
\hline
\end{tabular}

Fuels: the diesel fuel used was from the Swiss market, according to SN EN590. The used blend fuels were: Bu15 (15\% v butanol in diesel fuel) and Bu30 (30\% v butanol in diesel fuel). Some data of diesel-butanol blend fuels are given in the Table 1.

Lubricants: the lubricants were used according to the recommendations of the manufacturers, they were not specially changed or analyzed.

\section{Instrumentation}

Following instrumentation and equipment have been used.

Chassis dynamometer: Schenk 500 GS 60 with driver conductor system: Tornado, version 3.3 and CVS dilution system: Horiba CVS-9500T with Roots blower. There is an automatic air conditioning in the hall (for intake- and dilution air).

Test equipment for regulated exhaust gas emissions fulfils the requirements of the Swiss and European exhaust gas legislation. It consists of exhaust gas measuring system Horiba MEXA-9400H: CO, $\mathrm{CO}_{2}$ - infrared analyzers (IR), HCIR, HCFID, NO/NO $\mathrm{N}_{\mathrm{X}}$ CLA. The accuracy of these analyzers is $\pm 1 \%$ of full scale. The dilution ratio DF in the CVS-dilution tunnel is variable and can be controlled by means of the $\mathrm{CO}_{2}$-analysis. The accuracy of the entire exhaust gas measuring system, including analyzers, CVSsystem and chassis dynamometer is $\pm 4 \%$.

FTIR for non-legislated gaseous emissions: FTIR (Fourier Transform Infrared) Spectrometer (AVL SESAM) offers the possibility of simultaneous, time-resolved measurement of approx. 30 emission components - among oth- ers: $\mathrm{NO}, \mathrm{NO}_{2}, \mathrm{NO}_{\mathrm{x}}, \mathrm{NH}_{3}, \mathrm{~N}_{2} \mathrm{O}, \mathrm{HCN}, \mathrm{HNCO}, \mathrm{HCHO}$ and $\mathrm{MeCHO}$.

The sampling for measurements with FTIR was carried out at tailpipe. The sensitivity of this system is in the range of $1 \mathrm{ppm}$.

\subsection{Nanoparticle analysis}

The measurements of particle size distributions were conducted with different SMPS-systems, which enabled different ranges of size analysis (SMPS - scanning mobility particle sizer):

SMPS: DMA TSI 3081 \& CPC TSI 3772 (9.8-429 nm). nSMPS: nDMA TSI 3085 and CPC TSI 3776 (2-66 nm).

For measuring of the summary particle counts according to the legal guidelines (PMP) a CPC TSI 3790 was used. The accuracy of this device is given by the manufacturer with $\pm 10 \%$.

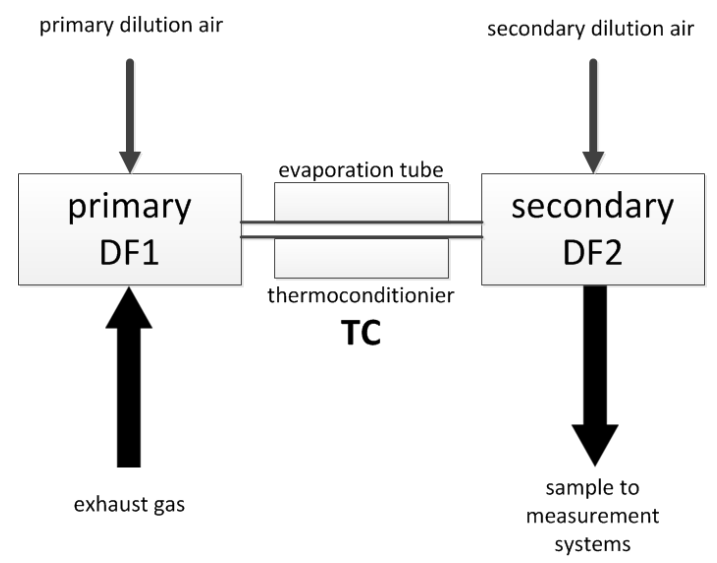

Fig. 1. Set-up of dilution stages and sample preparation for nanoparticle measurements

The Figure 1 shows the scheme of the used sample preparation for PN-measurements (ASET), which consists of 2-stage dilution and thermo-conditioning (TC) with sample heating at $300^{\circ} \mathrm{C}$.

The measuring set-up on chassis dynamometer and the possible sampling positions for particle analytics are represented in the Fig. 2. In the present tests, the sampling with both systems SMPS and CPC was carried out at tailpipe.

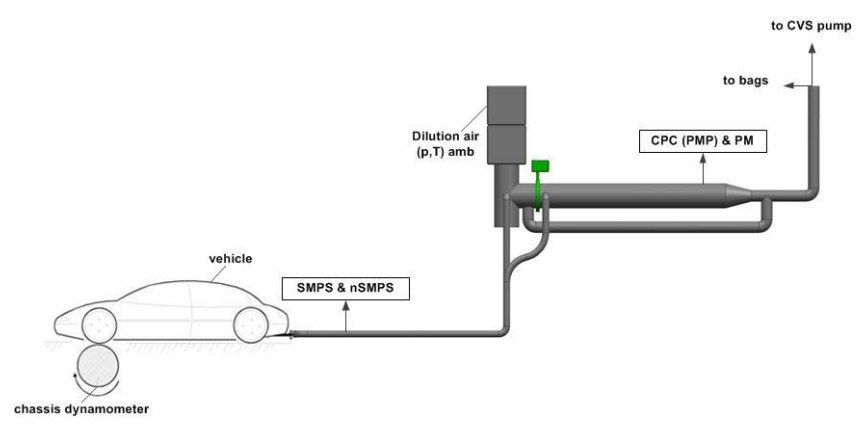

Fig. 2. Sampling of exhaust gas for analysis of particles

\section{Test procedures}

The tests were performed with both vehicles on a chassis dynamometer in the dynamic driving cycles WLTC and at constant speeds in the steady state cycle (SSC). 
WLTC represents different driving situations, like city, over-land and speedway, in the Fig. 3.

SSC consists of 20 min steps at constant vehicle speeds $95,45 \mathrm{~km} / \mathrm{h}$ and idling, which are driven from the highest to the lowest speed. These vehicle speeds respond to the average speeds in parts of the WLTC.

The test sequences with all fuels were identical: WLTC with cold start $\left(20-25^{\circ} \mathrm{C}\right), 10 \mathrm{~min}$ idling for bag evaluation, acceleration to $95 \mathrm{~km} / \mathrm{h}$ and continuation of the SSC.

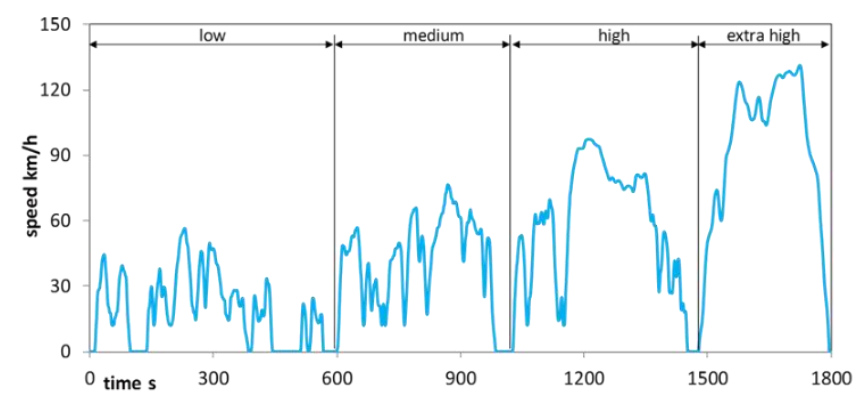

Fig. 3. WLTC driving cycle

\section{Cold start}

Repetitive cold start tests were performed with $\mathrm{Bu} 0 /$ $\mathrm{Bu} 15 / \mathrm{Bu} 30$, in two temperature domains: 20 to $25^{\circ} \mathrm{C}$, which is obtained by conditioning the vehicle in the laboratory hall and $-2^{\circ} \mathrm{C}$ to $4{ }^{\circ} \mathrm{C}$, which could be obtained by conditioning the vehicle outside during the winter period. The cold start (CS) in the higher temperature range can be considered as a summer cold start and it is described for simplification as $\mathrm{CS} @ 20^{\circ} \mathrm{C}$. The lower temperature represents the mild winter cold start and is designed in the further tests as $\mathrm{CS} @ 0^{\circ} \mathrm{C}$. The vehicles were started and operated at idling with on-line measurement of all emission components. After the measuring period at idling a WLTC was performed as conditioning for the next CS.

For the CS@0 $0^{\circ} \mathrm{C}$, the vehicle was pushed from outside into the test hall. For the start and for the following operation the intake air from the hall $\left(20-25^{\circ} \mathrm{C}\right)$ was available.

\section{Results}

\subsection{Comparisons of emissions of vehicles with older and with newer technology}

The Figure 4 shows the cumulated emissions of both vehicles in $\mathrm{WLTC}_{\text {cold }}$. The cumulated concentrations of respective components in the CVS-diluted exhaust gas are equivalent to the emitted mass of these components but enable the representation of relationships over the cycle time. It can be remarked, that with increasing Butanol content in the fuel $(\mathrm{BuXX})$, the cumulated emissions of $\mathrm{CO}$, $\mathrm{HC}$ and $\mathrm{NO}_{\mathrm{x}}$ in the $\mathrm{WLTC}_{\text {cold }}$ increase and PN decrease. Similar tendency, but less pronounced is also given in WLTC $_{\text {warm }}$ (not presented here).

Vehicle V2 (with newer technology) has much lower emission level and the differences between Bu00 and Bu30 are less significant.
The Figure 5 compares the SMPS particle size distributions (PSD) of both vehicles at two constant OP's (idling and $95 \mathrm{~km} / \mathrm{h}$ ). For better representation linear and logarithmic scales are used. In the linear scale, the Euro 6c (V2) particle numbers are not visible. In the logarithmic scale single counts (no distributions) are possible to remark for Euro 6c.

Without DPF (V1) the same tendency, like in previous research of this project, was found. With increasing BuXX there are: higher PN in nuclei mode and lower PN in accumulation mode, so that the summary PN is lower.

Similar results were found in other projects with alternative fuels, like RME, crude rapeseed oil, or ethanol [20, 21, 24]. The reasons of modified PSD-shapes with those fuels at engine-out are first of all: the higher oxygen content of the fuels and the modified chemistry of the nanoaerosol (especially the heaviest HC-fraction/SOF). For this modified chemistry the interaction of fuel with the lube oil layer in the combustion chambers plays a very important role [22, 23].

With DPF (V2) the particle count concentrations are strongly reduced (by 2 to 5 orders of magnitude), but they are higher with Bu30, than with Bu00. This also confirms the tendency found previously on engine with DPF and it is explained with another composition of the aerosol SOF and consequently modified behavior (nucleation, diffusion loses) in the exhaust and in the sampling systems.

More detailed explanation of this artefact is: the presence of Butanol in the blend fuel causes among others a modified structure of heavy SOF in exhaust. Part of these SOF, which pass the DPF in gaseous state of aggregation produce spontaneous condensates, which become semisolids in the sampling (analyzing) line and cannot be entirely eliminated by the sample treatment of the PN measuring system. These effects are only visible with a very low (near to ambient) PN emission level with DPF. Without DPF (Euro 2) the PN emission level is up to 5 ranges of magnitude higher and the effects from engine-out emissions are predominant. Despite that the DPF reduces or eliminates the nanoparticles down to the ambient count concentration level or below it.

The Figure 6 gives a sample of PSD results with SMPS (10-400 nm) and with nSMPS (2-66 nm). The results of both measuring systems correlate very well in the common measured size range $(10-66 \mathrm{~nm})$. Without DPF (V1) there are sporadic counts down to $5 \mathrm{~nm}$, with DPF (V2) there are no counts below $10 \mathrm{~nm}$. It can be stated that the filtration efficiency of a right-quality DPF is valid or even improved in the sub $23 \mathrm{~nm}$ size range. There are no differences of count concentrations with different investigated fuels.

The Figure 7 summarizes the comparisons of $\mathrm{NO}_{\mathrm{x}}$ and PN with both vehicles and with different fuels in $\mathrm{WLTC}_{\text {warm. }}$ The lower PN-emissions of vehicle V2 (with $\mathrm{DOC} / \mathrm{DPF} / \mathrm{SCR}$ ) are clearly visible. With increasing $\mathrm{BuXX}$ for vehicle $\mathrm{V} 1 \mathrm{NO}_{\mathrm{x}}$ increases and $\mathrm{PN}$ decreases very slightly, while for vehicle $\mathrm{V} 2$ there is no effect on $\mathrm{NO}_{\mathrm{x}}$ and there is a reduction of $\mathrm{PN}$. 
$\underline{\text { Vehicle } 1}$
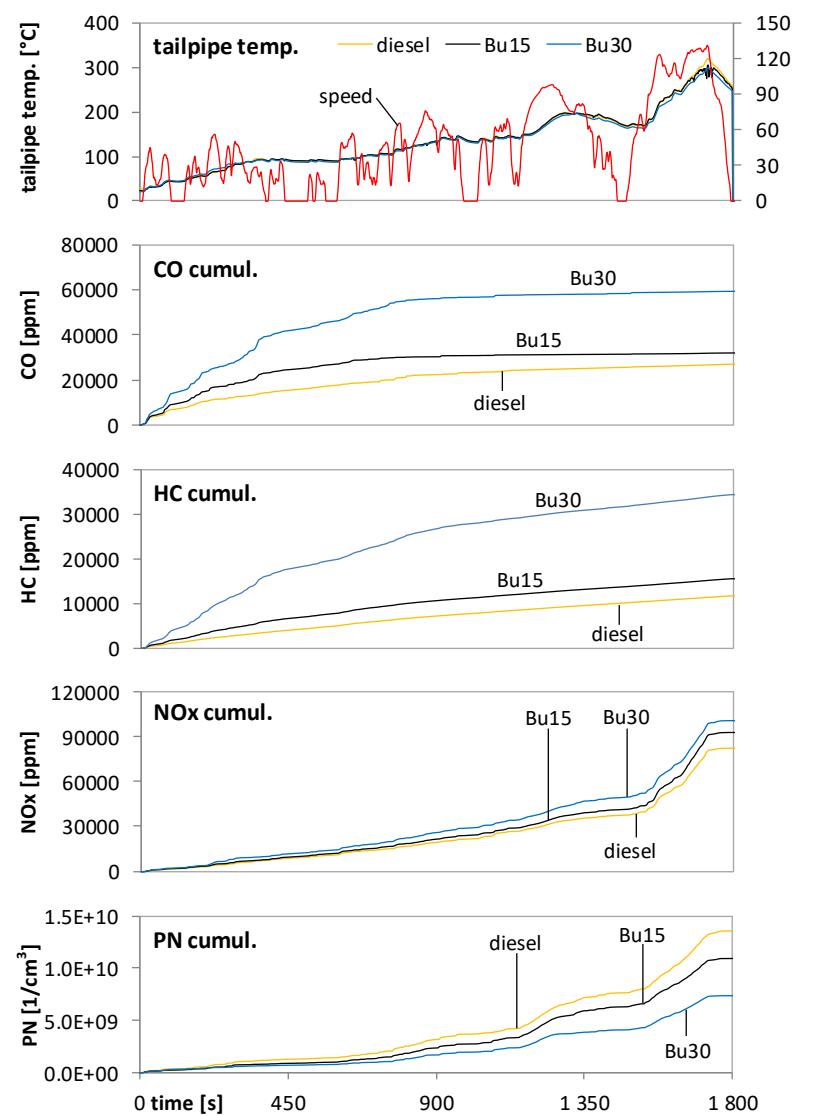

Fig. 4a. Cumulated diluted exhaust emissions and tailpipe temperatures in WLTC cold with different fuels, V1

SMPS
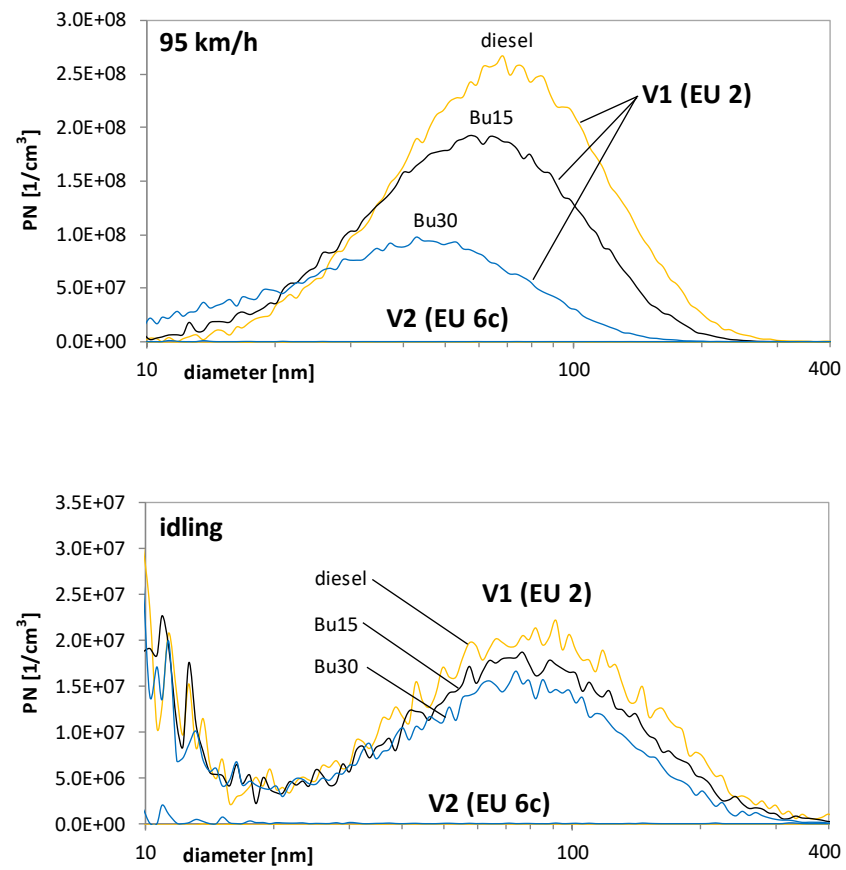

Fig. 5a. Comparison of the Particle Size Distribution (PSD) during the driving cycle SSC with different fuels and with vehicles V1 \& V2, (linear scale) $\underline{\text { Vehicle } 2}$
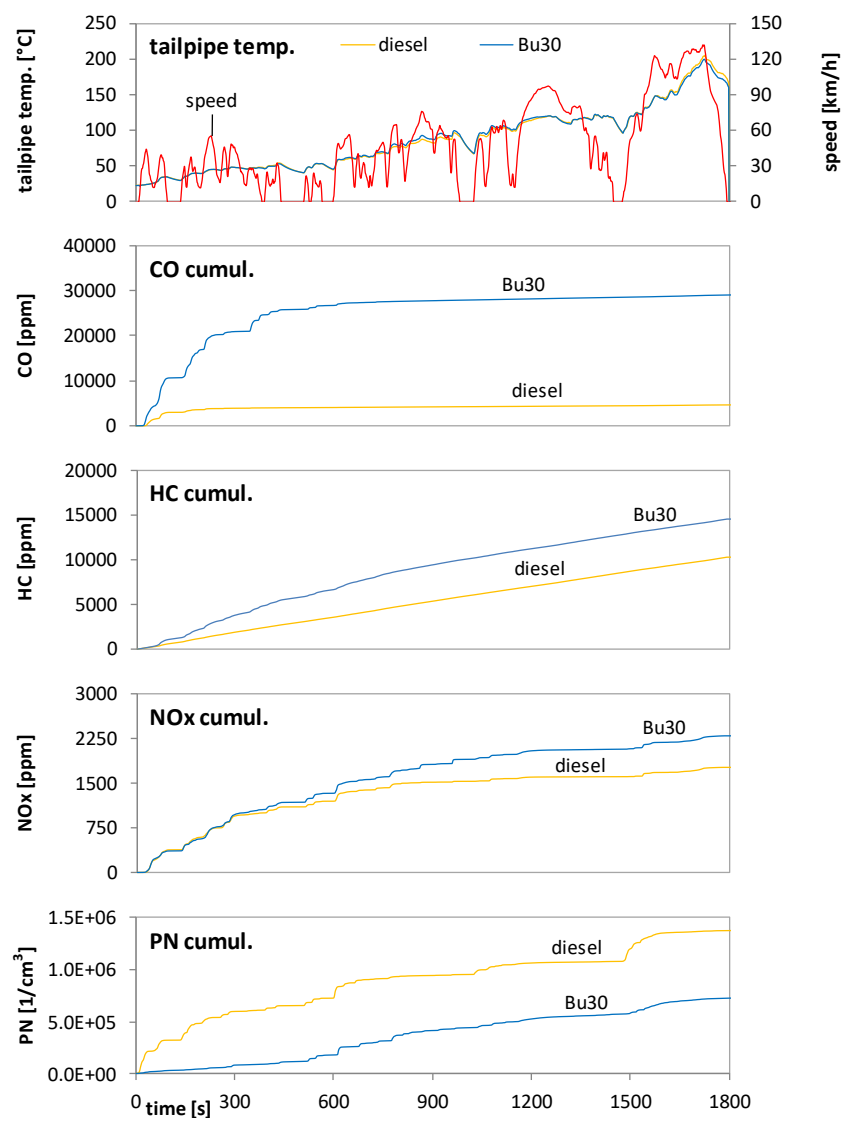

Fig. 4b. Cumulated diluted exhaust emissions and tailpipe temperatures in WLTC cold with different fuels, V2

\section{SMPS}
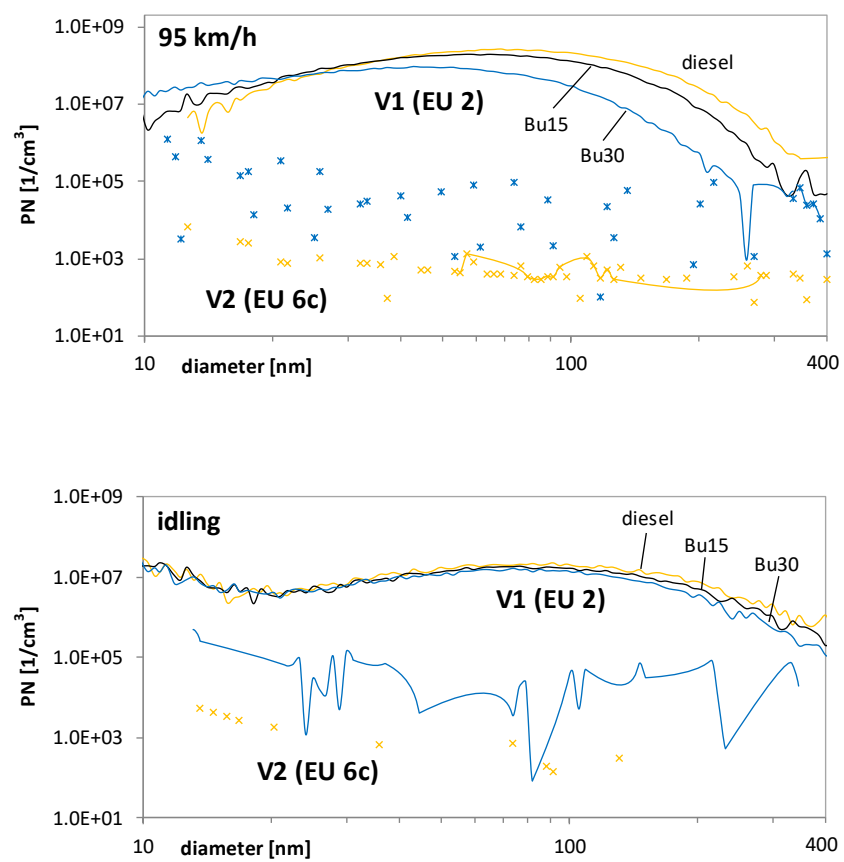

Fig. 5b. Comparison of the Particle Size Distribution (PSD) during the driving cycle SSC with different fuels and with vehicles V1 \& V2, (logarithmic scale) 

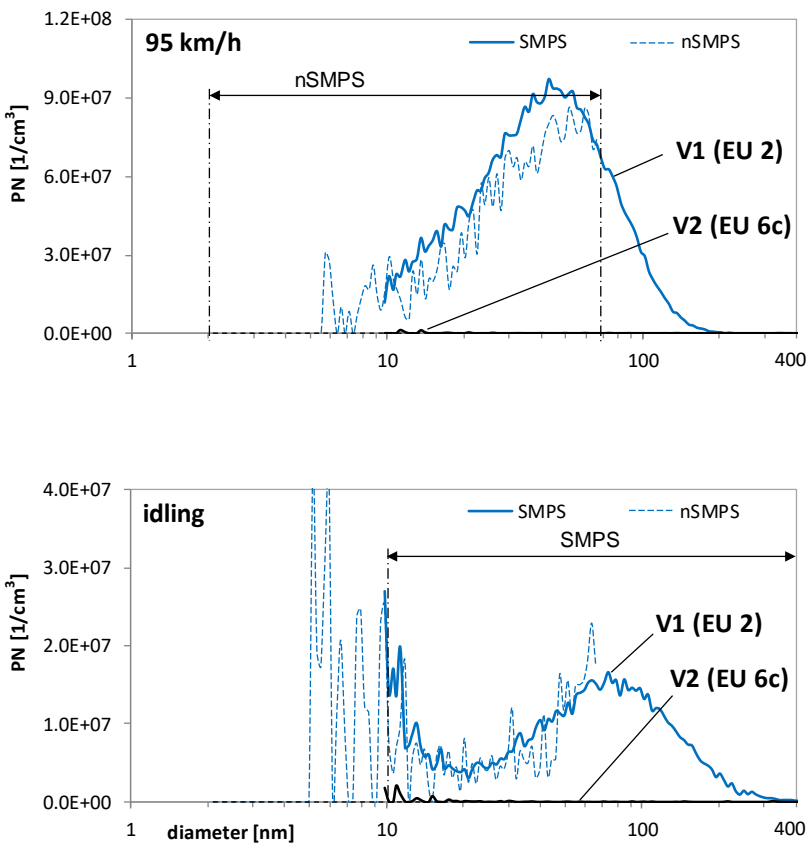

Fig. 6. Particle Size Distribution (PSD) during the SSC cycle in different ranges of size spectrum, Comparisons SMPS - nSMPS, Bu30, V1 \& V2
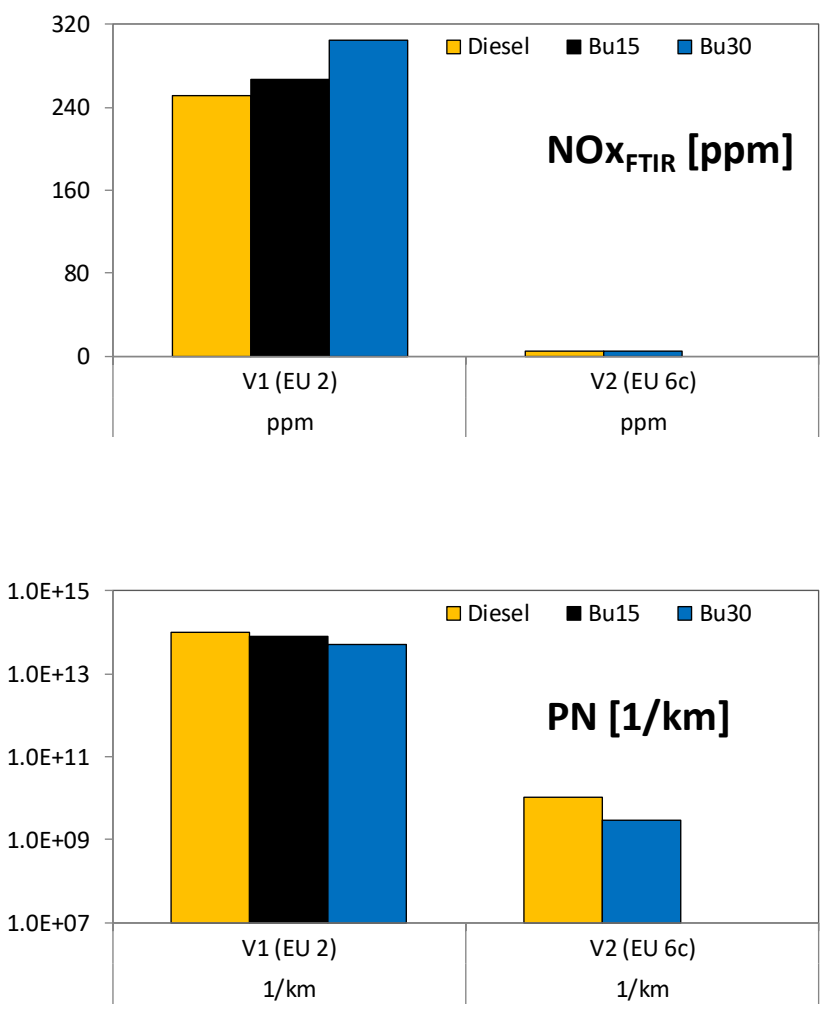

Fig. 7. Comparison of $\mathrm{NO}_{\mathrm{x}}$ - and $\mathrm{PN}$-emissions in WLTC warm with different fuels and with both vehicles V1 \& V2

\subsection{Non-legislated emissions of both vehicles}

Comparisons of non-legislated (legally not regulated) gaseous emissions, as average values in WLTC $_{\text {warm }}$ are represented in the Fig. 8 for both vehicles and for all investigated fuel variants. With higher Bu-content, especially with Bu30 the emissions of Formaldehyde (HCHO) and of Acetaldehyde (MeCHO) are clearly increased with $\mathrm{V} 1$ (older technology) while with V2 (new technology) these emissions are near to zero and there is no influence of $\mathrm{Bu}$ rate.

With the vehicle $\mathrm{V} 2$, the emission of $\mathrm{NO}_{2}$ is nearly eliminated and the emission of $\mathrm{N}_{2} \mathrm{O}$ is increased staying nevertheless at a very low absolute level $<4$ ppm.
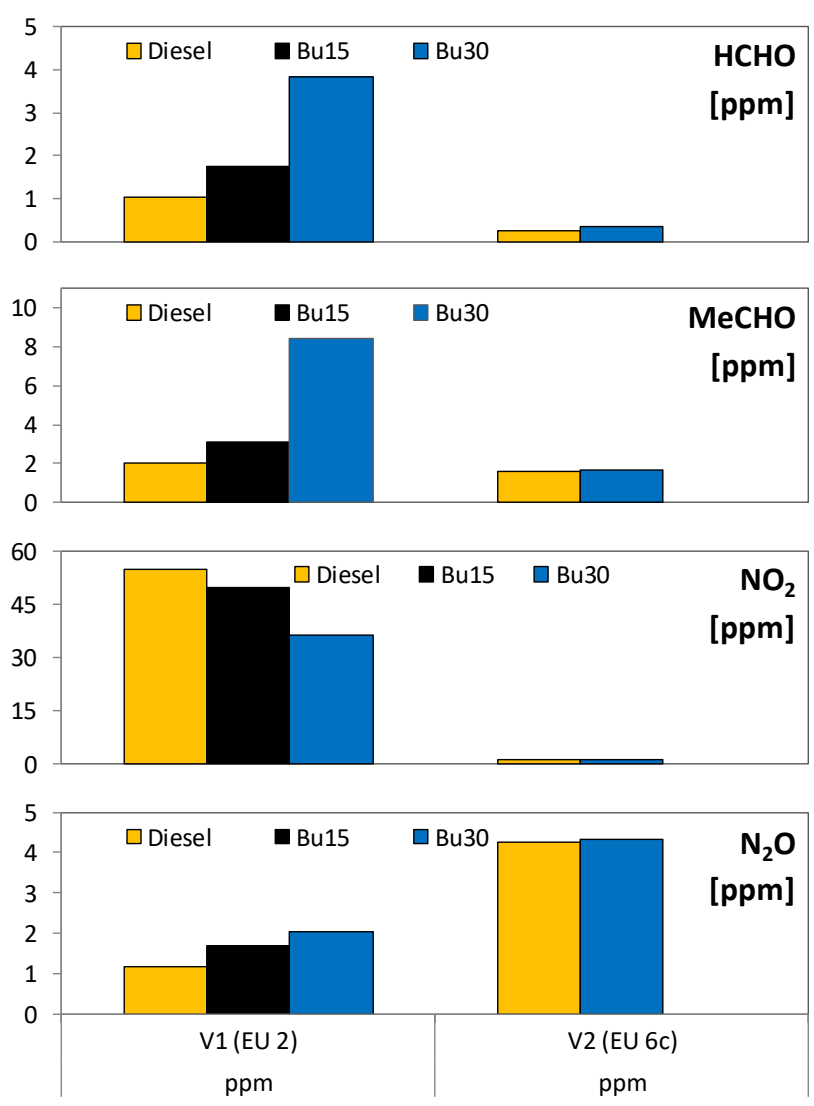

Fig. 8. Comparison of average non-legislated gaseous emissions in WLTC warm with different fuels and with both vehicles V1 \& V2, measured with FTIR at tailpipe

\subsection{Cold start}

The Figure 9 shows some non-legislated gaseous components, emitted by vehicle $\mathrm{V} 1$, comparing $\mathrm{Bu} 00 / \mathrm{Bu} 15 /$ $\mathrm{Bu} 30$ in two temperature domains of the $\mathrm{CS}: 0^{\circ} \mathrm{C}$ and $20^{\circ} \mathrm{C}$. All measurements at cold starts (CS) were performed with FTIR at tailpipe i.e. sampling position SP1.

With higher Bu-content the peaks of Formaldehyde $\mathrm{HCHO}$ and of Acetaldehyde MeCHO after CS increase. Starting with a lower temperature, these peak-values are higher and can attain for MeCHO $250 \mathrm{ppm}$.

During the warm-up of the exhaust system, between $180 \mathrm{~s}$ and $900 \mathrm{~s}$ idling time, there is a clear influence of BuXX on the production of formic acid $\mathrm{HCOOH}$. Nevertheless, it appears in insignificant concentrations (up to $7 \mathrm{ppm}$ at $0^{\circ} \mathrm{C}$ ). The ammonia $\mathrm{NH}_{3}$ concentrations in all CS-attempts were zero and are not further represented.

The Figure 10 compares the nanoparticle emissions with the fuels $\mathrm{Bu} 0 / \mathrm{Bu} 15 / \mathrm{Bu} 30$ at $\mathrm{CS}$ in both temperature ranges $0^{\circ} \mathrm{C} \& 20^{\circ} \mathrm{C}$. 

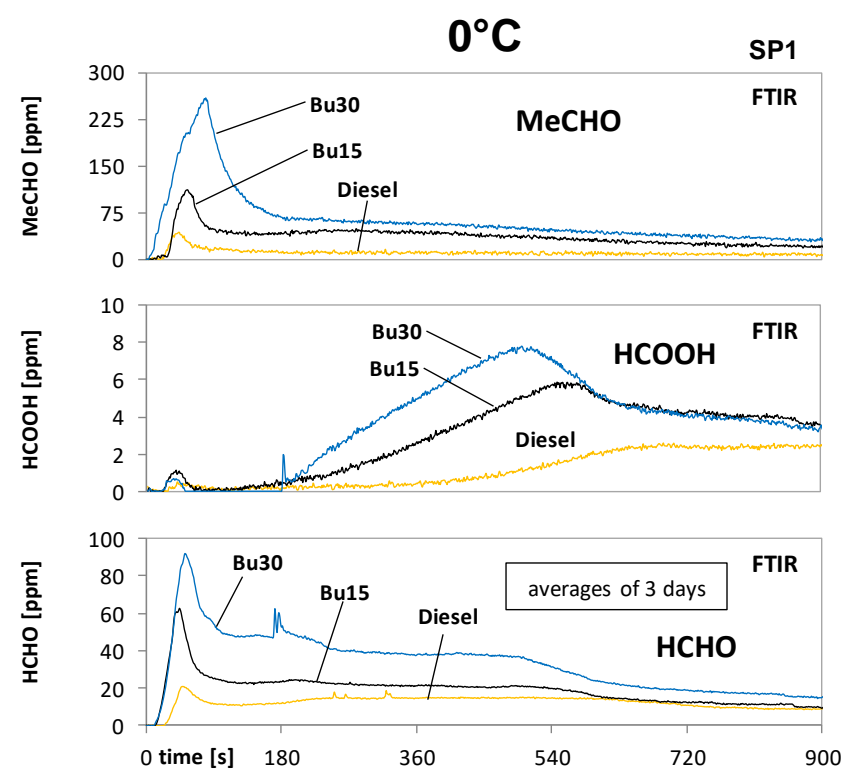

$20^{\circ} \mathrm{C}$
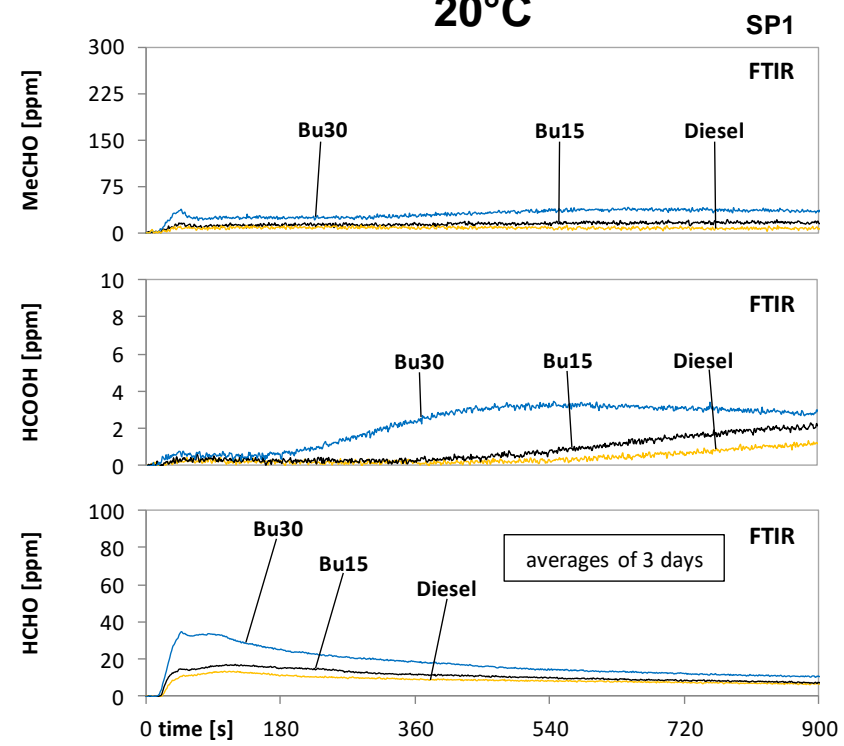

Fig. 9. Comparison of the non-legislated gaseous emissions during cold start (CS) at idling, with $\mathrm{Bu} 00 / 15 / 30$, measured with FTIR at tailpipe, vehicle V1

Let us remember that the condensation particle counter (CPC) analyzes simultaneously all particle sizes. It can perform dynamic measurements and according to PMPguidelines it has a cut-down at $23 \mathrm{~nm}$. The SMPS (scanning mobility particle sizer) in contrary needs a certain time (2-3 min) in order to carry out a scan and to indicate a particle size distribution (PSD) i.e. distribution of particle counts in function of their equivalent size.

During each CS \& warm-up in the present tests three successive SMPS-scans were performed (each one 5 minutes for scanning \& purging). With the progressing time and progressing warm-up the PN-level of the results was decreasing, showing the lowest values for the latest sample (this is not represented here). The $1^{\text {st }}$ sample was well repeatable and the PSD's in Fig. 10 are averages from three cold starts of the 1 st scan.
The most important information of Fig. 10 is, that during the CS Bu15 emits similar or slightly higher level of particle counts concentration, like $\mathrm{Bu} 0$, while $\mathrm{B} 30$ increases clearly the PN emissions. This increase is produced in the first 1.5 min after $\mathrm{CS}$ and originates mainly from the higher nuclei mode (with higher BuXX).
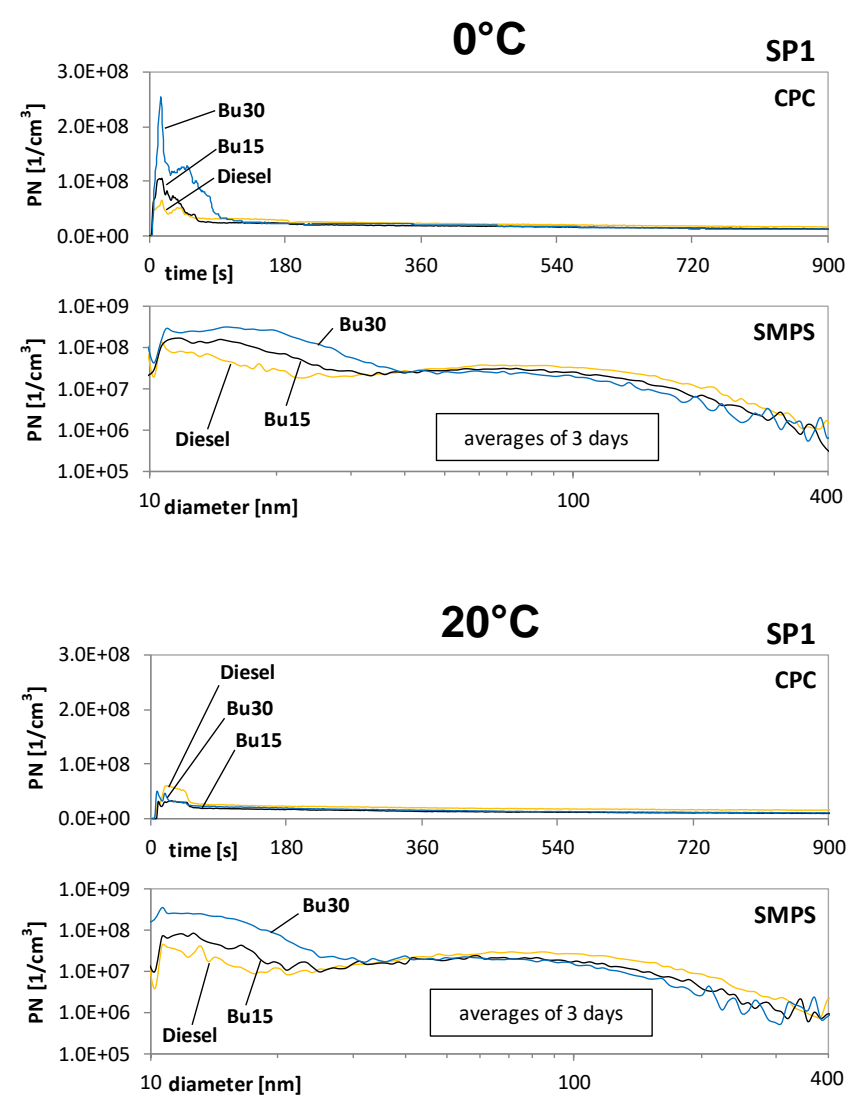

Fig. 10. Comparison of the particle counts during cold start (CS) at idling, with $\mathrm{Bu} 00 / 15 / 30$, measured with CPC and with SMPS at tailpipe, vehicle V1

The PN concentrations in accumulation mode nevertheless are lower with higher $\mathrm{BuXX}$ - this is similar finding like observed on engines.

Similar representations of emissions during the cold start tests in both temperature ranges $\left(0^{\circ} \mathrm{C}\right.$ and $\left.20^{\circ} \mathrm{C}\right)$ are given for vehicle V2 in the Figs 11 and 12. The most important observations are:

- with cold start (WLTC cold), the concentrations of Formaldehyde $\mathrm{HCHO}$ and Acetaldehyde $\mathrm{MeCHO}$ are with $\mathrm{Bu} 30$ higher than with $\mathrm{Bu} 00$; the absolute average values of those components are, nevertheless, insignificant $(0.5-8 \mathrm{ppm})$,

- the particle counts (PC) concentrations (after DPF) are very low, there are no particle size distributions, but occasional, scattered counts; in sub $23 \mathrm{~nm}$ size range, there are no counts at all; the PC's with Bu30 are higher than with $\mathrm{BuO0}$ - this is the effect of modified chemistry of the fuel and consequently modified interaction of fuel and of combustion with the lube oil, 
- at cold start, there are higher values of $\mathrm{CO}, \mathrm{HC}$ (not represented in these figures), $\mathrm{HCHO}$ and $\mathrm{MeCHO}$ with Bu30,

- the emissions of formic acid $\mathrm{HCOOH}$ are for this vehicle with newest technology not present; the Fig. 11 shows for $\mathrm{HCOOH}$ a noise below the resolution level of the analyzer (this in the sense of comparison with the older technology in the Fig. 9).
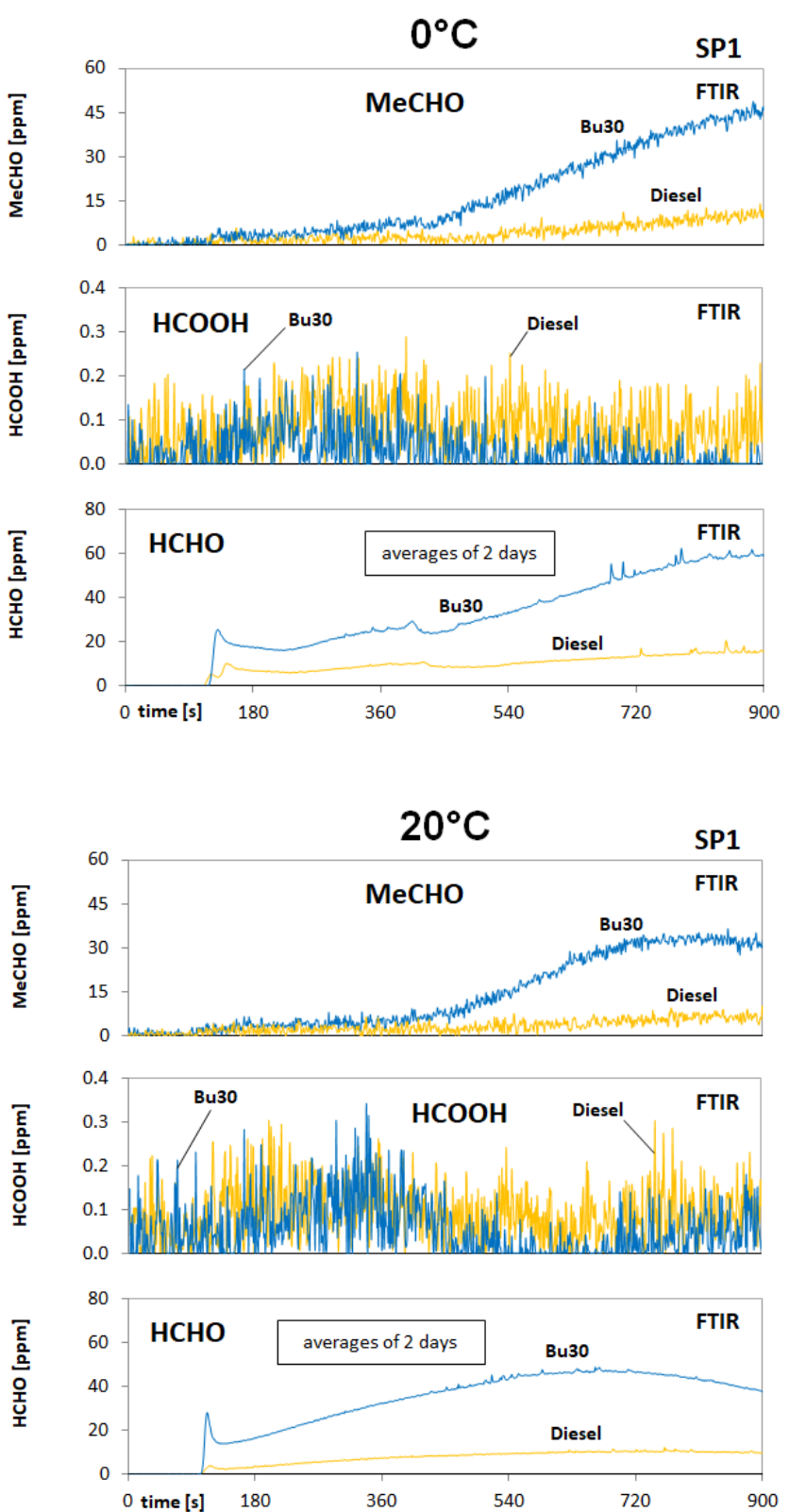

Fig. 11. Comparison of the non-legislated gaseous emissions during cold start (CS) at idling, with Bu00/Bu30, measured with FTIR at tailpipe,

$$
\text { vehicle V2 }
$$

Direct comparisons of emissions of both investigated vehicles, at $0^{\circ} \mathrm{C}$ cold start, are given in the following figures:

The Figure 13 shows the plots of the most prominent non-legislated components at cold start $0^{\circ} \mathrm{C}$. With an older technology, the higher $\mathrm{Bu}-$ content in fuel increases signifi- cantly the emission peaks of acetaldehyde (MeCHO) and formaldehyde (HCHO) at cold start. With a newer technology, this tendency is also present but at a very low and insignificant absolute emission level.
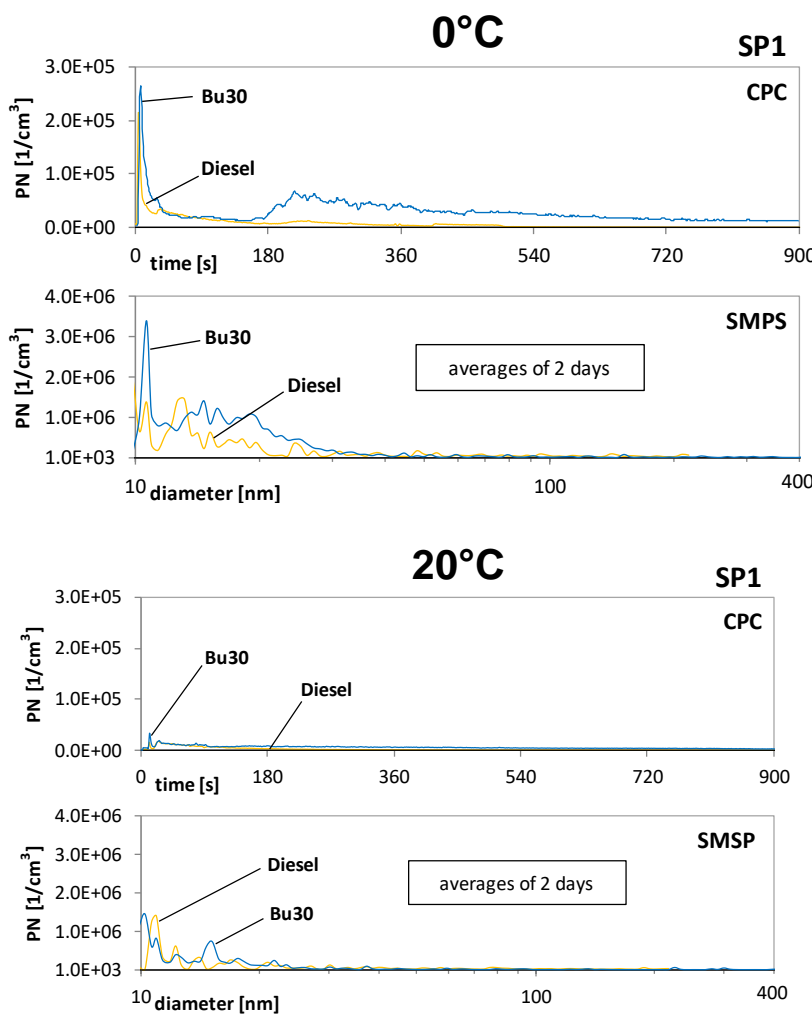

Fig. 12. Comparison of the particle counts during cold start (CS) at idling, with Bu00/Bu30, measured with CPC and with SMPS at tailpipe, vehicle V2
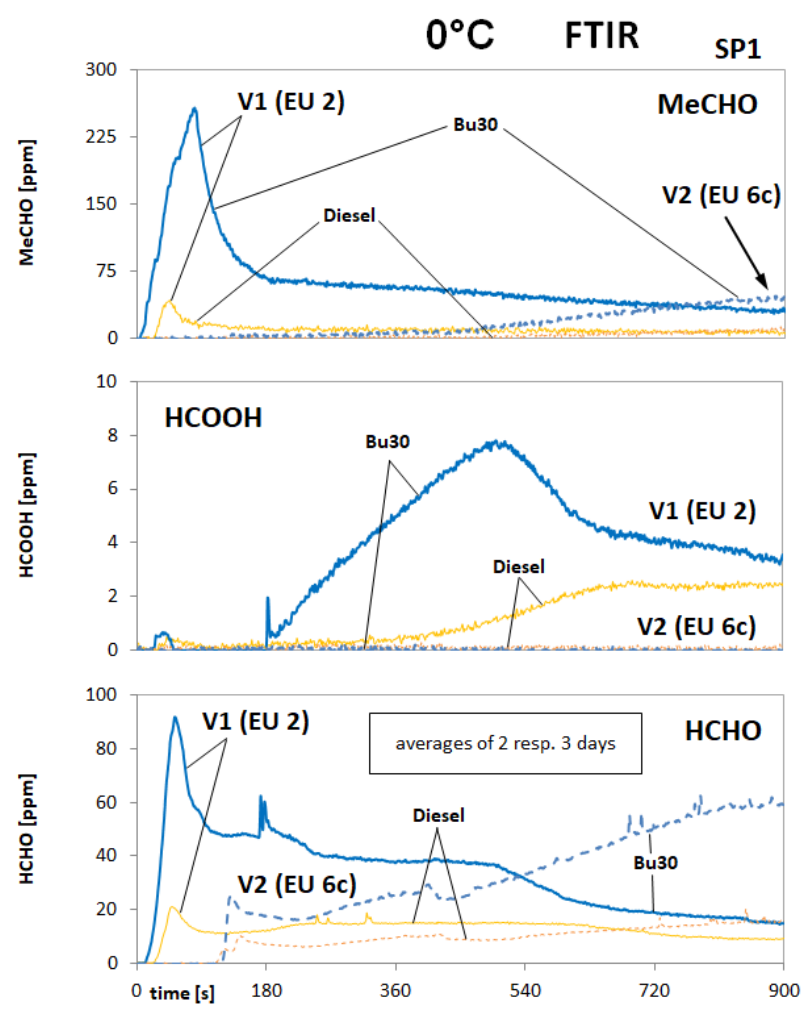

Fig. 13. Comparison of non-legislated gaseous exhaust emissions during cold start at $0^{\circ} \mathrm{C}$ and idling with different fuels, V1 \& V2 
The Figure 14 shows PN-emissions during and after the cold start at $0^{\circ} \mathrm{C}$ with both vehicles. The significantly lower PN-emission with DPF is confirmed.

The representation of summary particle counts indicated by CPC over time in the upper part of this figure shows for vehicle V2 (with DPF) higher PN with Bu30 (comparing to diesel). The major reason of that is the artefact, which is described by the Fig. 5. The resulting PN-concentrations after DPF at 900 [s] are for Bu30 in the range of $10^{4}$ which is still in the upper level of the possible ambient concentrations. The lower part of this figure confirms the findings of the Fig. 5.
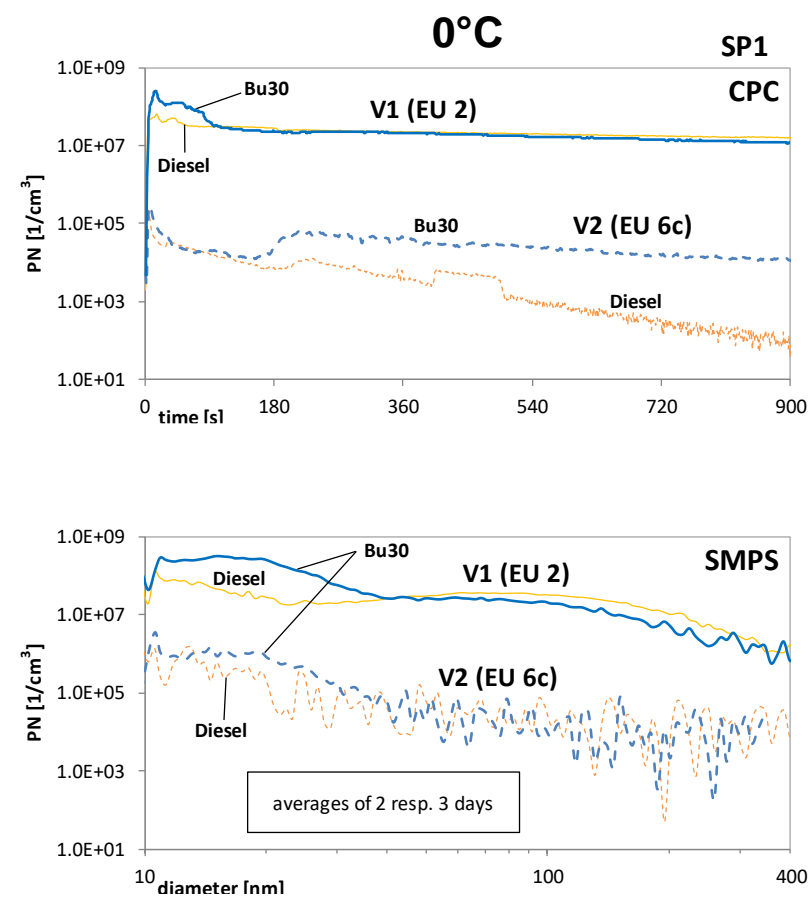

Fig. 14. Comparisons of the particles counts during cold start at $0^{\circ} \mathrm{C}$ and idling with different fuels, V1 \& V2

\section{Conclusions}

Using two vehicles with older (V1, Euro 2) and with actual (V2, Euro 6c) technical state of the art allowed to make some supplementary findings. The emissions of $\mathrm{CO}, \mathrm{HC}$ and $\mathrm{NO}_{\mathrm{x}}$ for both vehicles are with Bu30 in WLTC and at engine part load higher than with Bu00. With the modern exhaust aftertreatment technology (DOC/DPF/SCR/EGR), with a significantly lower emission level, these differences are smaller or not existing.

The non-regulated emissions in warm operation (WLTC) are for the modern car (V2) near to zero (Fig. 8). At cold start with an older technology (Euro 2), the higher
Bu-content in fuel increases significantly the emission peaks of acetaldehyde (MeCHO) and formaldehyde (HCHO). With a newer technology (Euro 6c), this tendency is also present but at a very low and insignificant absolute emission level.

Interesting facts about DPF-effects and nanoparticle emissions with/without DPF were confirmed: with the newest technology (Euro 6c), the particle counts concentrations (after DPF) are very low. There are no particle size distributions, but occasional, scattered counts. In sub $23 \mathrm{~nm}$ size range, there are no counts at all. This confirms the excellent filtration quality of solid particles of the right DPF's in good condition. The slightly increased particle counts with Bu30, which were observed in this research after DPF, are an effect of artefact due to the modified SOF-matrix of the nanoaerosol (in the Fig. 5).

Butanol, like several other biofuels modifies the interference with the lube oil. As a result, there are the tendencies of increasing the particle number concentrations in nuclei mode and of reducing them in accumulation mode, with the effect of reducing the total PN (summary of all sizes). This can be observed without DPF (V1). After DPF (V2) the PN-values are very low and such tendencies cannot be visible. Therefore, the higher Bu-content lowers the summary engine-out PN-emissions. With DPF, the PNlevel is so much reduced that the influence of fuel on PN is insignificant.

In summary, we can state that the butanol blends have some influences on engine-out emissions, but with the application of modern exhaust aftertreatment systems these influences are at tailpipe insignificant.

Another important result of the investigations is the assessment of the blend ratio limit. Due to the very low cetane number of butanol, this limit is approximately at $30 \%$ vol. butanol content. The cold startability at $0^{\circ} \mathrm{C}$ with Bu30 is already bad. Further improvements of $\mathrm{CN}$ by means of additives or other blended fuels were not the subject of this project.

For practical implementation of the butanol blend fuels in diesel engines it is important to mention that the questions of durability of the injection system due to lower lubricity of butanol blend fuels and durability of the lube oil were not investigated in the present project.

\section{Acknowledgements}

The institutions, which financially supported these research activities: Swiss Federal Office of Energy (BfE) and Swiss Federal Office of Environment (BAFU) are gratefully acknowledged.

\section{Nomenclature}

$\begin{array}{ll}\text { AFHB } & \text { Abgasprüfstelle FH Biel, CH } \\ \text { ASET } & \text { Aerosol Sampling and Evaporation Tube } \\ \text { ATS } & \text { aftertreatment system } \\ \text { BAFU } & \text { Bundesamt für Umwelt, (Swiss EPA) } \\ \text { BfE } & \text { Bundesamt für Energie } \\ \text { Bu } & \text { butanol } \\ \text { Bu30 } & 30 \% \text { vol butanol in diesel } \\ \text { BuXX } & \text { butanol portion in fuel XX vol \% }\end{array}$

CI

CLD

$\mathrm{CN}$

$\mathrm{CO}$

$\mathrm{CO}_{2}$

$\mathrm{CPC}$

$\mathrm{CR}$

CS compression ignition (diesel) chemoluminescence detector cetan number carbon monoxide carbon dioxide condensation particle counter common rail cold start 


\begin{tabular}{|c|c|c|c|}
\hline CVS & constant volume sampling & $\mathrm{NO}_{2}$ & nitrogen dioxide \\
\hline DF & dilution factor & $\mathrm{NO}_{\mathrm{x}}$ & nitric oxides \\
\hline DI & direct injection & NP & nanoparticles < $999 \mathrm{~nm}($ SMPS - range $)$ \\
\hline DiBut & Diesel-Butanol project & nSMPS & nano SMPS \\
\hline DOC & diesel oxidation catalyst & PCFE & particle count filtration efficiency \\
\hline DPF & Diesel Particle Filter & PM & particle mass \\
\hline DMA & differential mobility analyser & PMFE & particle mass filtration efficiency \\
\hline EGR & exhaust gas recirculation & PMP & Particle Measuring Program (ECE) \\
\hline $\mathrm{FE}$ & filtration efficiency & PN & particle number \\
\hline FID & flame ionization detector & PSD & particle size distribution \\
\hline FL & full load & RAI & reduction agent injection \\
\hline FOEN & Federal Office of Environment (BAFU), $\mathrm{CH}$ & $\mathrm{RR}$ & reduction rate \\
\hline FTIR & Fourier Transformation Infra-Red Analyzer & SCR & selective catalytic reduction \\
\hline $\mathrm{HC}$ & unburned hydrocarbons & SI & spark ignition \\
\hline $\mathrm{HCHO}$ & formaldehyde & $\mathrm{SOF}$ & soluble organic fraction \\
\hline $\mathrm{HCOOH}$ & formic acid & SMPS & Scanning Mobility Particle Sizer \\
\hline HNCO & isocyanic acid & SP1 & sampling position 1 (tailpipe) \\
\hline $\mathrm{Hu}$ & lower heat value & SSC & steady state cycle \\
\hline ICE & internal combustion engines & $\mathrm{TC}$ & thermo conditioner \\
\hline $\mathrm{MeCHO}$ & acetaldehyde & $\mathrm{T}_{\mathrm{exh}}$ & exhaust temperature \\
\hline NDIR & non-dispersive infrared & $\mathrm{TP}$ & tailpipe \\
\hline $\mathrm{N}_{2}$ & nitrogen & $\mathrm{V} 1, \mathrm{~V} 2$ & vehicle 1 , vehicle 2 \\
\hline $\mathrm{N}_{2} \mathrm{O}$ & nitrous oxide & WLTC & World Harmonized Light Duty Test Cycle \\
\hline $\mathrm{NH}_{3}$ & ammonia & & \\
\hline NO & nitrogen monoxide & & \\
\hline
\end{tabular}

\section{Bibliography}

[1] GIAKOUMIS, E.G., RAKOPOULOS, C.D., DIMARATOS, A.M. et al. Exhaust emissions with ethanol or n-butanol diesel fuel blends during transient operation: A review. Renewable and Sustainable Energy Reviews. 2013, 17, 170-190.

[2] RARBACH, M., SÖLTL, Y. Cellulosic ethanol from agricultural residues. MTZ, 2013, 4(74), 4-8. https://doi.org/10.1007/s38313-013-0034-3

[3] KAACK, M., WEISKIRCH, CH., EILTS, P. Alcoholic biofuels as an admixture component for conventional and alternative diesel combustion processes. MTZ. 2009, 7-8(70), 5865. https://doi.org/10.1007/BF03226971

[4] BRASSAT, A., THEWES, M., MÜTHER, M. et al. Massgeschneiderte Kraftstoffe aus Biomasse für Ottomotoren. MTZ. 2011, 12(72), 988-995. https://doi.org/10.1365/s35146-011-0212-2

[5] SIWALE, L., KRISTOF, L., ADAM, T. et al. n-butanoldiesel (D2) blend fired in a turbo-charged compression ignition engine. Performance and Combustion Characteristic. 2018, March.

http://dx.doi.org/10.5772/intechopen.72879

[6] LAPUERTA, M., HERNÁNDEZ, J.J., RODRIGUEZ-FERNÁNDEZ, J. et al. Emission benefits from the use of n-butanol blends in a Euro 6 diesel engine. International Journal of Engine Research. 2018, 19(10).

[7] SHUKLA, M.K., THARKE, G.D., SAXENA, R.C. et al. Butanol/diesel blends as a CI engine fuel: physicochemical and engine performance characteristics evaluation. TAE Technische Akademie Esslingen. $9^{\text {th }}$ International Colloquium "Fuels". 2013, January 15-17.

[8] HAN, X., YANG, Z., WANG, M. et al. Clean combustion of n-butanol as a next generation biofuel for diesel engines. Applied Energy. 2017, 198, 347-359.

https://doi.org/10.1016/j.apenergy.2016.12.059

[9] SOLOIU, V., DUGGAN, M., HARP, S. et al. PFI (port fuel injection) of n-butanol and direct injection of biodiesel to attain LTC (low-temperature combustion) for low-emissions idling in a compression engine. Elsevier Energy. 2013, 52, 143-154.

[10] WALLNER, T., ICKES, A., LAWYER, K. et al. Higher alcohols in multi-component blends with gasoline - experimental and analytical assessment. 14. Tagung "Der Arbeitsprozess des Verbrennungsmotors", TU Graz. 2013, September.

[11] TORNATORE, C., MARCHITTO, L., VALENTINO, G. et al. Optical diagnostics of the combustion process in a PFI SI boosted engine fueled with butanol-gasoline blend. Energy. 2012, 45(1), 277-287. https://doi.org/10.1016/j.energy.2012.03.006

[12] MEROLA, S., TORNATORE, C., MARCHITTO, L. et al. Experimental investigations of butanol-gasoline blends effects on the combustion process in a SI engine. International Journal of Energy and Environmental Engineering. 2012, 11(3). https://doi.org/10.1186/2251-6832-3-6

[13] MARCHITTO, L., MAZZEI, A., MEROLA, S.S. et al. Optical investigations of combustion process in SI and CI engines fuelled with butanol blends. TAE Technische Akademie Esslingen. $9^{\text {th }}$ International Colloquium "Fuels". 2013, January $15-17$.

[14] IRIMESCU, A., TORNATORE, C., MEROLA, S.S. et al. Integrated diagnostics for combustion investigation in a DISI engine fueled with butanol and gasoline at different load settings. TAE Technische Akademie Esslingen. 10th International Colloquium „Fuels“, Stuttgart/Ostfildern. 2015, January 20-22.

[15] GU, X., HUANG, Z., CAI, J. et al. Emission characteristics of a spark-ignition engine fuelled with gasoline-n-butanol blends in combination with EGR. Fuel. 2012, 93, 611-617. https://doi.org/10.1016/j.fuel.2011.11.040

[16] LIU, H., WANG, X., ZHANG, D. et al. Investigation on blending effects of gasoline fuel with n-butanol, DMF, and ethanol on the fuel consumption and harmful emissions in a GDI vehicle. Energies. 2019, 12(10), 1845.

https://doi.org/10.3390/en12101845 
[17] VOJTISEK-LOM, M., PECHOUT, M., MAZAC, M. Realword on-road exhaust emissions from an ordinary gasoline car operated on E85 and on butanol-gasoline blend. SAE Technical Paper 2013-24-0102. 2013. https://doi.org/10.4271/2013-24-0102

[18] US DOE CO-OPTIMA Publications Library: https://www.energy.gov/eere/bioenergy/co-optimapublications-library-0

[19] ENGELMANN, D., CZERWINSKI, J., NAUROY, H. et al. Use of butanol blend fuels on diesel engines - effects on combustion and emissions. SAE Technical Paper 2020-010333. 2020. https://doi.org/10.4271/2020-01-0333

[20] STEPIEN, Z., CZERWINSKI, J., URZEDOWSKA, W. et al. Research on emissions and engine lube oil deterioration of diesel engines with biofuels (RME). SAE Technical Paper 2011-01-1302. 2011. https://doi.org/10.4271/2011-01-1302

\begin{abstract}
Danilo Engelmann, DEng. - Professor at the University of Applied Sciences, Biel-Bienne, Switzerland.

e-mail: danilo.engelmann@bfh.ch
\end{abstract}

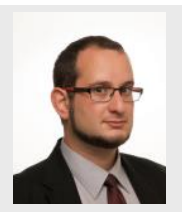

Prof. Jan Czerwinski, DEng. - Professor Emeritus at the University of Applied Sciences, Biel-Bienne, Switzerland, CJ Consulting.

e-mail: cjcons19@gmail.com
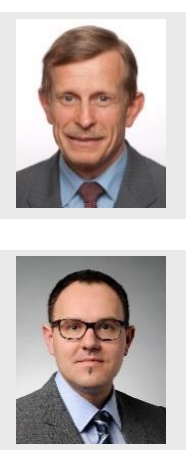

[21] CZERWINSKI, J., COMTE, P., STEPIEN, Z. et al. Effects of ethanol blend fuels E10 \& E85 on the non-legislated emissions of a flex fuel passenger car. SAE Technical Paper 2016-01-0977. 2016. https://doi.org/10.4271/2016-01-0977

[22] HADLER, J., LENSCH-FRANZEN, CH., GOHL, M. et al. Concept for analysing and optimising oil emission. MTZ Worldwide. 2014, 1(75), 24-29. https://doi.org/10.1007/s38313-014-0006-2

[23] HADLER, J., LENSCH-FRANZEN, CH., GOHL, M. et al. Emission reduction a solution of lubricant composition, calibration and mechanical development. MTZ Worldwide. 2015, 9(76), 30-33. https://doi.org/10.1007/s38313-015-0040-8

[24] CZERWINSKI, J., ZIMMERLI, Y., NEUBERT, T. et al. Injection, combustion and (nano) particle emissions of a modern HD-diesel engine with GTL, RME \& ROR. SAE Technical Paper 2007-01-2015. 2007. https://doi.org/10.4271/2007-01-2015

Pierre Comte, Dipl.-Ing. HTL - University of Applied Sciences, Biel-Bienne, Switzerland. e-mail: pierre.comte@bfh.ch

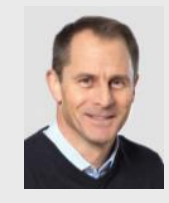

Stephan Renz, CEO - Renz Consulting, Basel, Switzerland.

e-mail: renz.btr@swissonline.ch
Peter Bonsack, MSc ME - Federal Office for the Environment FOEN, Bern, Switzerland.

e-mail: peter.bonsack@bafu.admin.ch 